\title{
Synergism of Antithyroid Agent and Estrogen in the Induction of Experimental Fatty Livers in Growing Chicks
}

\author{
Yukio Akiba, Kazuaki TaKahashi, Atsuro Matsuda \\ and Tatsuro Matsumoto \\ Department of Animal Science, Faculty of Agriculture, \\ Tohoku University, Sendai 980, Japan
}

Excessive lipid deposition in liver is involved in fatty livers and fatty liver-hemorrhagic syndrome (FLHS) and is influenced by nutritional factors and metabolic states ${ }^{1,2}$. Recently, HAGHIGHI-RAD and Polin ${ }^{3)}$ and AKIBA et al. ${ }^{4)}$ have indicated that enhanced lipid deposition in liver and hepatic hemorrhages are associated with high level of plasma estradiol in laying hens. This is confirmed by previous findings that estrogen administration induced hepatic steatosis in immature chicks ${ }^{5 \sim 11)}$ and hepatic hemorrhages in immature chicks ${ }^{12,13)}$.

Administration of antithyroid agent, such as propylthiouracil, induced lipid deposition in liver of immature chicks ${ }^{11,14 \sim 16}$. In the previous paper ${ }^{11)}$ from this laboratory, an induction of excessive lipid deposition in liver was induced by synergetic action of antithyroid agent and estrogen in growing chicks.

The following experiment was conducted to study effects of graded doses of antithyroid agent and estrogen, and their interactions on lipid deposition in liver of growing chicks.

\section{Materials and Methods}

Ninty-six White Leghorn male chicks (14 days old) were divided into 16 groups of 6 chick each with $4 \times 4$ factorial arrangement. They were housed in wire cages under controlled light (14 hours light photoperiod) in air-conditioned room at $25^{\circ} \mathrm{C}$ and fed ad libitum a practical-type mash diet containing $20.7 \% \mathrm{CP}$ and $2.9 \mathrm{kcal}$ of metabolizable energy per gram for 13 days. Propylthiouracil (PTU, Sigma Chemical Company, USA) and dienestrol diacetate (DD, Sigma Chemical Company, USA) were added to the diet at levels of 0 , $0.025,0.05$ and $0.10 \%$ and at levels of $0,0.04,0.08$ and $0.16 \%$, respectively.

Eight hours after deprivation of the diet, blood was collected by cardiac puncture with a heparinized syringe prior to slaughter and centrifuged for 15 minutes at $1,500 \times \mathrm{g}$ and the plasma was stored at $-20^{\circ} \mathrm{C}$ for later analysis. Liver lipid was extracted by the method of FoLCH et al. ${ }^{17)}$ and determined gravimetrically. Total lipid content in plasma was determined by the method of BRAGDON ${ }^{18)}$ and triglyceride content in the liver and plasma was determined by the method of FLETCHER ${ }^{19)}$. Activity of glutamate oxalacetate transaminase (GOT) in plasma was determined by a modified method of ReItman and Frankel ${ }^{20)}$, using colorimetric measuring kits (Wako Pure Chemical Industries, Japan). The data were subjected to analysis of variance ${ }^{21)}$. 


\section{Results}

Table 1 shows feed intake, body weight gain and liver weight. Feed intake was increased by administration of DD. The increased feed intake by $\mathrm{DD}$ appears to be reduced with increasing PTU in the diet. Body weight gain during 13 days was increased by DD and lowered by PTU. The maximal body weight gain was demonstrated in chicks given $0.025 \%$ PTU and $0.04 \% \mathrm{DD}$, concomitantly, and it was lowered with increasing DD and PTU in the diet as shown in Fig. 1A. Liver weight was increased with increasing DD in the diet and concomitant addition of PTU (0.025\%) induced further enlargement of liver, though administration of PTU over $0.05 \%$ was less effective (Fig. 1B).

Total lipid and triglyceride contents in the liver are presented in Table 2 and Figs. 1C and 1D. PTU without a concomitant administration of DD had no influence on hepatic lipid content (wet \%). Concurrent administration of PTU and DD over the level of $0.025 \%$ and $0.04 \%$, respectively, resulted in a significant increase of the liver lipid content. An increasing effect in liver lipid deposition (mg/liver) by DD was obviously demonstrated and it was extensively augmented by a concomitant administration of PTU at $0.025 \%$. Effect of

Table 1. Effects of administration of PTU and/or DD on feed intake, body weight gain and liver weight in chicks ${ }^{1}$

\begin{tabular}{|c|c|c|c|c|c|}
\hline \multicolumn{2}{|c|}{ Treatment $^{2}$} & \multirow{2}{*}{$\begin{array}{c}\text { Feed } \\
\text { intake } \\
(\mathrm{g})\end{array}$} & \multirow{2}{*}{$\begin{array}{l}\text { Body weight } \\
\text { gain } \\
\text { (g ) }\end{array}$} & \multicolumn{2}{|c|}{ Liver weight } \\
\hline \multicolumn{2}{|c|}{$(\%$ in diet $)$} & & & (g) & $(\mathrm{g} / 100 \mathrm{~g} \mathrm{BW})$ \\
\hline 0 & 0 & 420 & $168 \pm 11^{\operatorname{def} 3}$ & 8. $0 \pm 1.0^{\mathrm{h}}$ & $2.68 \pm 0.21^{\mathrm{i}}$ \\
\hline 0 & 0.04 & 499 & $173 \pm 3^{\text {def }}$ & $8.4 \pm 1.4^{\mathrm{h}}$ & $2.75 \pm 0.43^{\mathrm{i}}$ \\
\hline 0 & 0.08 & 474 & $193 \pm 12^{\mathrm{c}}$ & $11.6 \pm 1.8^{\mathrm{g}}$ & $3.57 \pm 0.61^{\mathrm{h}}$ \\
\hline 0 & 0.16 & 480 & $199 \pm 23^{b}$ & $18.1 \pm 2.4^{\mathrm{d}}$ & $5.45 \pm 0.72^{\mathrm{e}}$ \\
\hline 0.025 & 0 & 487 & $163 \pm 29^{f g}$ & $10.7 \pm 1.4^{g}$ & $3.67 \pm 0.61^{\mathrm{h}}$ \\
\hline 0.025 & 0.04 & 479 & $211 \pm 16^{\mathrm{a}}$ & $18.1 \pm 4.4^{\mathrm{cd}}$ & $5.27 \pm 1.08^{\mathrm{ef}}$ \\
\hline 0.025 & 0.08 & 487 & $206 \pm 20^{\mathrm{ab}}$ & $22.7 \pm 1.6^{\mathrm{b}}$ & $6.71 \pm 0.36^{c}$ \\
\hline 0.025 & 0.16 & 444 & $176 \pm 16^{\mathrm{d}}$ & $24.2 \pm 4.2^{\mathrm{a}}$ & $8.11 \pm 1.28^{\mathrm{a}}$ \\
\hline 0.05 & 0 & 372 & $143 \pm 8 \mathrm{gh}$ & $10.2 \pm 0.8^{g}$ & $3.61 \pm 0.31^{\mathrm{h}}$ \\
\hline 0.05 & 0.04 & 420 & $166 \pm 24^{\mathrm{efg} g}$ & 13. $6 \pm 2.8^{\mathrm{f}}$ & $4.50 \pm 0.65^{g}$ \\
\hline 0.05 & 0.08 & 484 & $178 \pm 12^{\mathrm{d}}$ & $19.3 \pm 2.1^{\mathrm{c}}$ & $6.33 \pm 0.45^{\mathrm{d}}$ \\
\hline 0.05 & 0.16 & 408 & $154 \pm 20^{g}$ & $20.5 \pm 4.2^{\mathrm{c}}$ & $7.25 \pm 1.01^{\mathrm{b}}$ \\
\hline 0.10 & 0 & 418 & $140 \pm 14^{\mathrm{h}}$ & $10.3 \pm 0.6^{g}$ & $3.84 \pm 0.20^{\mathrm{h}}$ \\
\hline 0.10 & 0.04 & 424 & $172 \pm 8^{\mathrm{def}}$ & $14.8 \pm 1.3^{\mathrm{g}}$ & $4.87 \pm 0.48^{f g}$ \\
\hline 0.10 & 0.08 & 436 & $159 \pm 25^{\mathrm{fg}}$ & $16.2 \pm 2.5^{\mathrm{e}}$ & $5.55 \pm 0.41^{\mathrm{e}}$ \\
\hline 0.10 & 0.16 & 413 & $156 \pm 23^{\mathrm{fg}}$ & $18.7 \pm 2.5^{\mathrm{d}}$ & $6.59 \pm 0.81^{\mathrm{cd}}$ \\
\hline \multicolumn{6}{|c|}{ Analysis of variance } \\
\hline \multicolumn{2}{|c|}{ PTU } & & $\mathrm{P}<0.01$ & $\mathrm{P}<0.01$ & $\mathrm{P}<0.01$ \\
\hline \multicolumn{2}{|l|}{$\mathrm{DD}$} & & $\mathrm{P}<0.01$ & $\mathrm{P}<0.01$ & $\mathrm{P}<0.01$ \\
\hline \multicolumn{2}{|c|}{$\mathrm{PTU} \times \mathrm{DD}$} & & $\mathrm{P}<0.01$ & $\mathrm{P}<0.01$ & $\mathrm{P}<0.01$ \\
\hline
\end{tabular}

1 Chicks were fed diet added PTU and/or DD for 13 days from 14 th day of age.

2 Abbreviations: PTU, propylthiouracil; DD, dienestrol diacetate.

3 Mean \pm SD of 6 observations. Means with different superscripts in columns are significantly $(\mathrm{P}<0.05)$ different. 
Table 2. Effects of administration of PTU and/or DD on total lipid and triglyceride contents in liver of chicks

\begin{tabular}{|c|c|c|c|c|c|}
\hline \multicolumn{2}{|c|}{ Treatment } & \multicolumn{2}{|c|}{ Liver total lipids } & \multicolumn{2}{|c|}{ Liver triglycerride } \\
\hline \multicolumn{2}{|c|}{ (\% in diet) } & (\% wet weight) & (mg/liver) & (\% total lipids) & (mg/liver) \\
\hline 0 & 0 & $4.5 \pm 0.3^{\mathrm{i} t}$ & $369 \pm 53^{h}$ & $27.4 \pm 9.0^{\mathrm{e}}$ & $99 \pm 36^{f}$ \\
\hline 0 & 0.04 & $4.6 \pm 0.3^{\mathrm{i}}$ & $379 \pm 38^{h}$ & $37.1 \pm 2.3^{\mathrm{cde}}$ & $141 \pm 18^{\mathrm{ef}}$ \\
\hline 0 & 0.08 & $6.2 \pm 1.3^{\mathrm{e}}$ & $735 \pm 243^{\mathrm{fgh}}$ & $47.7 \pm 10.0^{\mathrm{bc}}$ & $349 \pm 146^{\text {de }}$ \\
\hline 0 & 0.16 & $13.9 \pm 1.5^{\mathrm{a}}$ & $2510 \pm 394^{\mathrm{b}}$ & $64.4 \pm 5.4^{\mathrm{a}}$ & $1626 \pm 333^{\mathrm{a}}$ \\
\hline 0.025 & 0 & $4.7 \pm 0.4^{\mathrm{hi}}$ & $503 \pm 87 \mathrm{gh}$ & $34.2 \pm 10.9^{\text {cde }}$ & $174 \pm 63^{\text {ef }}$ \\
\hline 0.025 & 0.04 & $8.9 \pm 3.1^{c}$ & $1457 \pm 549^{\text {cde }}$ & $60.0 \pm 17.7^{\mathrm{ab}}$ & $1078 \pm 756^{\mathrm{bc}}$ \\
\hline 0.025 & 0.08 & $12.5 \pm 3.2^{\mathrm{b}}$ & $2825 \pm 788^{\mathrm{ab}}$ & $72.1 \pm 5.7^{\mathrm{a}}$ & $1942 \pm 519^{a}$ \\
\hline 0.025 & 0.16 & $13.3 \pm 3.6^{\mathrm{ab}}$ & $3258 \pm 1490^{\mathrm{a}}$ & $65.1 \pm 12.6^{\mathrm{a}}$ & $2073 \pm 996^{\mathrm{a}}$ \\
\hline 0.05 & 0 & $4.8 \pm 0.7^{\mathrm{ehi}}$ & $495 \pm 109 \mathrm{gh}$ & $29.7 \pm 11.7^{\mathrm{de}}$ & $156 \pm 96^{\mathrm{ef}}$ \\
\hline 0.05 & 0.04 & $6.1 \pm 1.4^{\mathrm{eg}}$ & $852 \pm 342^{\text {efgh }}$ & $43.8 \pm 18.7^{\mathrm{bcd}}$ & $417 \pm 266^{\text {de }}$ \\
\hline 0.05 & 0.08 & $8.6 \pm 1.5^{c}$ & $1685 \pm 412^{\mathrm{cd}}$ & $64.5 \pm 7.1^{\mathrm{a}}$ & $1079 \pm 248^{b c}$ \\
\hline 0.05 & 0.16 & $8.4 \pm 2.4^{c d}$ & $1796 \pm 942^{c}$ & $59.8 \pm 15.0^{\mathrm{ab}}$ & $1157 \pm 871^{b}$ \\
\hline 0.10 & 0 & $4.5 \pm 0.2^{\mathrm{i}}$ & $466 \pm \quad 37 \mathrm{gh}$ & $24.0 \pm 7.3^{\mathrm{e}}$ & $113 \pm 39^{f}$ \\
\hline 0.10 & 0.04 & $7.2 \pm 1.9^{\mathrm{de}}$ & $1077 \pm 310^{\text {cdef } g}$ & $36.8 \pm 13.1^{\text {cde }}$ & $418 \pm 215^{\mathrm{de}}$ \\
\hline 0.10 & 0.08 & $7.6 \pm 2.7^{c d}$ & $1276 \pm 641^{\mathrm{cdef}}$ & $45.9 \pm 18.3^{\text {bcd }}$ & $680 \pm 599^{c d}$ \\
\hline 0.10 & 0.16 & $6.6 \pm 1.0^{\text {de }}$ & $1320 \pm 293^{\mathrm{cdef}}$ & $45.9 \pm 6.5^{\mathrm{bcd}}$ & $613 \pm 191^{\mathrm{cd}}$ \\
\hline \multicolumn{6}{|c|}{ Analysis of variance } \\
\hline \multicolumn{2}{|c|}{ PTU } & $\mathrm{P}<0.01$ & $\mathrm{P}<0.01$ & $\mathrm{P}<0.01$ & $\mathrm{P}<0.01$ \\
\hline \multicolumn{2}{|c|}{ DD } & $\mathrm{P}<0.01$ & $\mathrm{P}<0.01$ & $\mathrm{P}<0.01$ & $\mathrm{P}<0.01$ \\
\hline \multicolumn{2}{|c|}{$\mathrm{PTU} \times \mathrm{DD}$} & $\mathrm{P}<0.01$ & $\mathrm{P}<0.01$ & $\mathrm{P}<0.01$ & $\mathrm{NS}^{2}$ \\
\hline
\end{tabular}

1 Mean \pm SD of 6 observations. Means with different superscripts in columns are significantly $(\mathrm{P}<0.05)$ different.

2 Not significant.

DD was proportionally reduced with increasing PTU over $0.025 \%$. The maximal deposition of lipids in the liver was obtained by concurrent administration of PTU $(0.025 \%)$ and DD $(0.08 \sim 0.16 \%)$. Similarly hepatic triglyceride content was increased by the administration of DD $(0.16 \%)$ or concurrent administration of PTU and DD but it was not increased by PTU, per se.

Total lipid and triglyceride contents and GOT activity in plasma are shown in Table 3 and Figs, 1E and 1F. Total lipid (Fig. 1E) and triglyceride in the plasma are increased by PTU and were extensively increased by DD feeding. Marked increases of lipid and triglyceride contents in the plasma were demonstrated in the chicks administered PTU and DD, concurrently. And those were maintained even when level of PTU in the diet increasing, but this trends are clearly different from that in the liver lipid and triglyceride contents. Plasma GOT activity was elevated by administration of PTU but it was not affected by DD. Concomitant administration of DD in addition to PTU increased plasma GOT activity (Fig. $1 \mathrm{~F})$. 

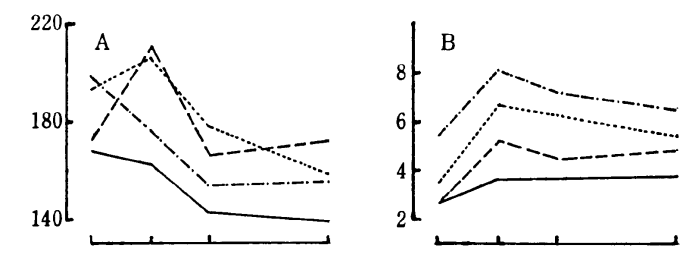

A : Body weiht gain (g).

B : Liver weight ( $\mathrm{g} / 100 \mathrm{~g}$ body weight).

C : Liver total lipids (mg/liver)
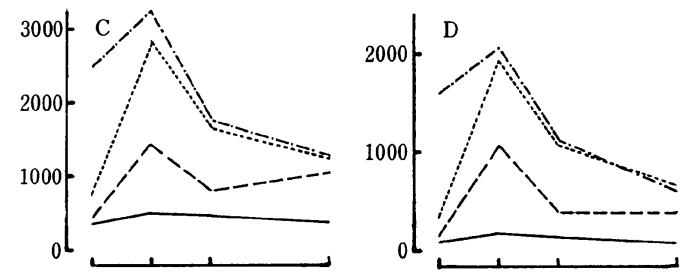

$\mathrm{D}$ : Liver triglyceride (mg/liver).

E : Plasma lipids $(\mathrm{mg} / 100 \mathrm{~m} l)$.

F : Plasma GOT activity (Karmen unit)

DD $0 \%$

DD $0.08 \%$

..... DD $0.04 \%$

-.-. DD $0.16 \%$
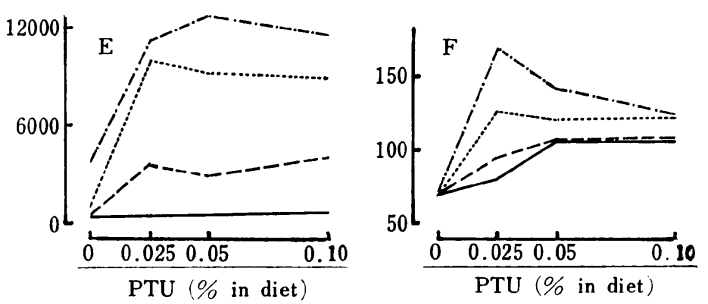

Fig. 1. Body weight gain, liver weight, total lipid and triglyceride contents in the liver, plasma lipids and plasma GOT activity influenced by administration of PTU and/or DD in chicks.

Table 3. Effects of administration of PTU and/or DD on total lipid and triglyceride contents and GOT activity in plasma of chicks

\begin{tabular}{|c|c|c|c|c|}
\hline \multicolumn{2}{|c|}{ Treatment } & \multicolumn{3}{|c|}{ Plasma } \\
\hline \multicolumn{2}{|c|}{ (\% in diet $)$} & $\begin{array}{l}\text { Total lipid } \\
(\mathrm{mg} / 100 \mathrm{~m} l)\end{array}$ & $\begin{array}{l}\text { Triglyceride } \\
(\mathrm{mg} / 100 \mathrm{~m} l)\end{array}$ & $\begin{array}{c}\text { GOT }^{1} \\
\text { (Karmen unit) }\end{array}$ \\
\hline 0 & 0 & $327 \pm 84^{\mathrm{d}^{2}}$ & $69 \pm \quad 9^{f}$ & $72 \pm 5^{\text {ef }}$ \\
\hline 0 & 0.04 & $364 \pm 175^{\mathrm{cd}}$ & $161 \pm 49^{e}$ & $71 \pm 5^{\mathrm{ef}}$ \\
\hline 0 & 0.08 & $1313 \pm 875^{b c}$ & $678 \pm 283^{\mathrm{d}}$ & $66 \pm 5^{f}$ \\
\hline 0 & 0.16 & $3868 \pm 2439^{b}$ & $2450 \pm 931^{\mathrm{cd}}$ & $72 \pm 6^{\mathrm{ef}}$ \\
\hline 0.025 & 0 & $534 \pm 355^{c}$ & $215 \pm 64^{\mathrm{e}}$ & $83 \pm 19^{\text {def }}$ \\
\hline 0.025 & 0.04 & $3612 \pm 2616^{b}$ & $1827 \pm 1353^{\mathrm{cd}}$ & $96 \pm 18^{\text {cde }}$ \\
\hline 0.025 & 0.08 & $9992 \pm 2939^{a}$ & $6048 \pm 1978^{b}$ & $125 \pm 47^{\mathrm{bc}}$ \\
\hline 0.025 & 0.16 & $11063 \pm 4110^{\mathrm{a}}$ & $9426 \pm 1405^{\mathrm{a}}$ & $169 \pm 40^{\mathrm{a}}$ \\
\hline 0.05 & 0 & $574 \pm 141^{\mathrm{c}}$ & $214 \pm 25^{\mathrm{e}}$ & $106 \pm 19^{\mathrm{cd}}$ \\
\hline 0.05 & 0.04 & $3047 \pm 2457^{b}$ & $1670 \pm 1248^{d}$ & $108 \pm 32^{\mathrm{cd}}$ \\
\hline 0.05 & 0.08 & $9157 \pm 2488^{a}$ & $6769 \pm 2424^{b}$ & $121 \pm 29^{b c}$ \\
\hline 0.05 & 0.16 & $12607 \pm 3929^{a}$ & $9065 \pm 3041^{a}$ & $143 \pm 31^{b}$ \\
\hline 0.10 & 0 & $767 \pm 233^{c}$ & $341 \pm 149^{c}$ & $106 \pm 26^{\mathrm{cd}}$ \\
\hline 0.10 & 0.04 & $4202 \pm 2594^{\mathrm{b}}$ & $3097 \pm 1929^{c}$ & $108 \pm 21^{\mathrm{cd}}$ \\
\hline 0.10 & 0.08 & $8685 \pm 1611^{a}$ & $6765 \pm 2123^{\mathrm{b}}$ & $123 \pm 21^{b c}$ \\
\hline 0.10 & 0.16 & $11538 \pm 1145^{\mathrm{a}}$ & $9272 \pm 855^{a}$ & $125 \pm 26^{\mathrm{bc}}$ \\
\hline \multicolumn{5}{|c|}{ Analysis of variance } \\
\hline PTU & & $\mathrm{P}<0.01$ & $\mathrm{P}<0.01$ & $\mathrm{P}<0.01$ \\
\hline $\mathrm{DD}$ & & $\mathrm{P}<0.01$ & $\mathrm{P}<0.01$ & $\mathrm{P}<0.01$ \\
\hline $\mathrm{PTU} \times \mathrm{DD}$ & & $\mathrm{P}<0.01$ & $\mathrm{P}<0.01$ & $\mathrm{P}<0.01$ \\
\hline
\end{tabular}

1 Abbreviation: GOT, glutamate-oxalacetate transaminase activity.

2 Mean \pm SD of 6 observations. Means with different superscripts in columns are significantly $(\mathrm{P}<0.05)$ different. 


\section{Discussion}

The injection of estrogen has been confirmed to induce hepatic steatosis and hyperlipidemia in immature chicks ${ }^{5-11}$. However, effect of oral administration of estrogen on the hepatic lipid content is not conclusive since LOREN2 ${ }^{22}$ ) reported a small increase in liver lipid caused by dietary DD, whereas WOLFORD ${ }^{23)}$ and ROBERSON and TRUJILLO ${ }^{24)}$ stated that liver lipid was not elevated by feeding $\mathrm{DD}$ at $0.007 \%$ in the diet of laying hens. The present study, however, clearly proved that feeding DD over $0.08 \%$ in the diet caused a pronounced hepatic steatosis which is associated with hyperlipidemia and increase in feed intake and body weight gain in accordance with our previous paper ${ }^{11}$. Additionally, it is noteworthy that the extent of increase in the plasma lipid by feeding DD is more pronounced than that in the liver lipid (Table 2 and 3), indicating that DD stimulates not only overproduction of lipid in the liver but also secretion of the lipid from the liver in chicks.

It has been shown in immature chicks that administration of PTU induced hypothyroidism ${ }^{25,26)}$ and thereby resulting in enlargement of thyroid gland and an excessive lipid deposition in liver ${ }^{11,14 \sim 16)}$. The increase of liver lipid by PTU feeding was also confirmed in the present study but it was less striking compared with the other findings ${ }^{14 \sim 16)}$ and was not fortified with increasing PTU in the diet. This could be ascribed to less feed intake in chicks fed higher levels of PTU (Table 1) because energy intake has shown to be involved in regulation of hepatic lipid deposition ${ }^{27.28)}$.

Plasma transaminase activity has been ascertained to be elevated when liver impairment is artificially induced by administration of carbon tetrachloride ${ }^{29,30)}$ and force-feeding a high energy diet ${ }^{31}$ ) in chicks. Plasma GOT activity, in this experiment, was increased by feeding PTU and further intensified by concomitant feeding with DD, suggesting that treatments with PTU or PTU +DD induced liver dysfunction accompanied with the hepatic steatosis in growing chicks.

Marked lipid deposition in the liver and hyperlipidemia were caused by the concomitant feeding of DD with $0.025 \%$ PTU and were mainly due to overproduction of triglyceride (Fig. 1). This evidence confirms our previous findings ${ }^{11}$ ) that hepatic steatosis and hyperlipidemia were caused by synergetic action of PTU and DD. Some of chicks given both $0.025 \%$ PTU and DD $(0.08 \sim 0.16 \%)$ had hepatic hemorrhages, indicating that experimental fatty liver with hemorrhages could be induced by concurrent administration of PTU and DD in growing chicks, and also suggesting that this experimental fatty liver would be useful as a laboratory model for the detection of fatty liver-preventing factors.

The excessive lipid deposition in the liver induced by concurrent administration of PTU $(0.025 \%)$ and DD was proportionally reduced with increasing PTU in the diet, though plasma lipid and triglyceride contents were maintained even when increasing PTU in diet. It was already suggested in our previous paper ${ }^{11}$ that feeding of PTU at a low level $(0.025 \%)$ in the diet may retard secretion of lipid from the liver. But in the present experiment, it seems likely that high levels of PTU (over $0.025 \%$ ) in the diet rather enhance secretion of lipids which was excessively produced in the liver by feeding DD, and thereby resulting in the gradual decrease of liver lipid. The reason for these phenomena are not well understood, but these observations could be supported by the findings in rats ${ }^{32}$ ) 
that output of triglyceride from perfused liver was accelerated by the injection of PTU.

\section{Summary}

Lipid and triglyceride content in liver and plasma and plasma transaminase activity were determined in 14-day-old male chicks given graded levels of propylthiouracil (PTU, $0,0.025,0.05$ and $0.10 \%)$ and/or dienestrol diacetate (DD, 0, 0.04, 0.08 and $0.16 \%$ ) in diet with $4 \times 4$ factorial arrangement for 13 days. Plasma transaminase activity was increased by feeding PTU or PTU + DD. Feeding PTU or DD induced significant increase of liver weight and lipid and triglyceride contents in the liver and plasma. Marked hepatic steatosis and hyperlipidemia were caused by concurrent administration of PTU $(0.025 \%)$ and DD $(0.08 \sim 0.16 \%)$ and those were gradually reduced with increasing PTU in the diet. It is suggested that experimental fatty livers are induced by synergetic actions of antithyroid agent and estrogen in growing chicks.

\section{Literature}

1) Butler, E. J.: Avian Pathol., 5, 1, 1976.

2) Jensen, L. S.: Fed. Proc., 38, 2631, 1979.

3) Haghighi-Rad, F. and D. Polin: Poult. Sci., 60, 2278, 1981.

4) Акiba, Y., L. S. Jensen, C. R. Barb and R. R. Kraeling: J. Nutr., 112, 299, 1982.

5) Lorenz, F. W.: Vit. Horm., 12, 235, 1954.

6) Balnave, D.: J. Endocrinol., 42, 119, 1968.

7) Kudzman, D. J., P. M. Hagstad and R. E. Stoll: J. Clin. Invest., 22, 423, 1973.

8) Yu, Y-L. and R. R. Marquardt: Comp. Biochem. Physiol., 46 B, 749, 1973.

9) Balnave, D. and J. Pearce: J. Endocrinol., 61, 29, 1974.

10) Pearce, J. and D. Balnave: Biochem. Pharmacol., 24, 1843, 1975.

11) Akiba, Y., K. Takahashi, M. Kimura, S. Hirama T. Matsumoto: Br. Poult. Sci. (in press).

12) Pearson, A. W. and E. J. Butler: Res. Vet. Sci., 24, 82, 1978.

13) Polin, D. and J.H. Wolford: J. Nutr., 107, 873, 1977.

14) Evans, J. D., N. O. Buryk, P. J. Middleton and H. G. Schwarts: Endocrinol., 70, 465, 1962.

15) Raheja, K. L., J. D. Snedecor and R. A. Freedland: Com. Biochem. Physiol., 39 B, 833, 1971.

16) Raheja, K. L. and W. G. Linscheer: Comp. Biochem. Physiol,, 61 A, 31, 1978.

17) Folch, J., M. Lees and G. H. Sloan-Stanley: J. Biol. Chem., 226, 497, 1957.

18) Bragdon, J.H.: Lipids and the Steroid Hormones in Clinical Medicine. Sunderman, F. W. and F. W. Sunderman eds., pp 9, Lippincott, Philadelphia and Montreal, 1960.

19) Fletcher, M. J.: Clin. Chim. Acta, 22, 393, 1968.

20) Reitman, S. and S. Frankel: Am. J. Clin. Pathol., 28, 56, 1957.

21) Snedecor, G. W. and W.G. Cochran: Statistical Methods, 6th ed., The Iowa University Press, USA, 1967.

22) Lorenz, F. W. and G. H. Bachman: Poult. Sci., 26, 419, 1947.

23) Wolford, J. H.: Poult. Sci., 50, 1331, 1971.

24) Roberson, R. H. and V. Trujillo: Poult. Sci., 54, 715, 1975.

25) Акiba, Y. and T. Matsumoto: Jpn. J. Zootech. Sci., 48, 757, 1977.

26) Аківа, Y. and T. Mатsumoto: Jpn. J. Zootech. Sci., 49, 61, 1978.

27) Akiba, Y., A. Horigane and T. Matsumoto: Jpn. J. Zootech. Sci., 49, 54, 1978.

28) Wolford, J. H. and D. Polin: Poult. Sci., 53, 65, 1974.

29) Fowler, J.S. L.: J. Com. Pathol., 80, 465, 1970.

30) Narashimhan, T. R. and S. G. Nair: Acta Vet., 19, 269, 1974.

31) Аківа, Y. and T. Матsumoto: J. Nutr., 110, 1112, 1980.

32) Keys, W. G. and M. Heimberg: J. Clin. Invest., 64, 182, 1979. 


\title{
鵎比ナの害験的脂肪肝形成に対する抗甲状腺物質 とエストロジェンの相乗作用
}

\author{
秋葉征夫・高橋和昭・松田敦郎・松本達郎
}

東北大学農学部，仙台沛 980

鵎の実験的脂肪朋の形成に対する抗甲状腺物質とエス トロジェンの作用と，それらの相乗作用について検討し た。14 日歯令の白色レグホーン種雄ヒナを供試して, 抗甲 状腺物質 propylthiouracil (PTU) および合成エストロ ジェン dienestrol diacetate (DD) を飼料に混合して13 日間給〕jした。試験区として, PTU 投与 4 レベル（0, $0.025 ， 0.05,0.10 \%)$ および DD投方 4 レぶル $(0,0.04$, $0.08 ， 0.16 \%$ ）を組合わせた 16 区を設分し，各区に6妆 芝割り当てた。

増体量はPTU 投「で減少し，DD投与で増加した。 DDによる増体量の増加は PTU 0.025\%の间時投与で さらに倠した。肝臓重量はPTU投与で若干増加し た。DD 投与ではその投与量に比例して朋臓重量が増加 する傾向がみられ，それは PTUの问時投与により著し
く穴進した。肝臓中脂質およびトリグリセリド量は, DD の投与量に比例して増加し，さらに PTU $0.025 \%$ の同時投与で著しく増加した。しかし，PTU の投与量 をさらに増すと，それらは減少する傾向にあった。PTU 0. 025\% および DD 0. 08〜0. 16\%の相乗効果により, 肝 臓脂質量は対照区の約 10 倍に増加し, 一部の肝臓には出 血点も認められた。血漿脂質およびトリグリセリド量は PTU+DD 投与により著しく増加し, 湆脂血症を呈し た。血漿中トランスアミナーゼ活性は, PTU 0.025\% と DD 0.08〜0.16\% の同時投「jにより著しく上昇し，肺 機能の低下が推察された。以上の事から，鷂ヒナを用い て，抗甲状腺物質とェストロジェンの相乗作用による脂 肪肝をつくり出すことが可能である。

（家禽会誌，19，238～244，1982） 